\title{
Analysis of Student Anxiety Level in Science Integrated Learning Process
}

\author{
Try Susanti ${ }^{1}$, Dwi Gusfarenie ${ }^{2}$ and Rairil Fitri ${ }^{3}$ \\ \{trysusanti@uinjambi.ac.id ${ }^{1}$ and DwiGusfarenie@uinjambi.ac.id ${ }^{2}$ \} \\ Department of Biologi Education, State Islamic University of Sulthan Thaha Saifuddin Jambi,Jl. \\ Jambi-Ma. Bulian, Kab. Muaro Jambi,Indonesia ${ }^{1,2,3}$
}

\begin{abstract}
This study aims to determine the students anxiety level in learning at Madrasah Tsanawiyah Negeri 3 Kabupaten Tebo. This research is a qualitative descriptive research with the subject of research of class VIII students consisting of 2 classes. Data obtained through observation, documentation, interview and questionnaire on students covering physical, cognitive and emotional aspects. The results showed that students anxiety level in class VIII A was 50\% (medium category) on physical aspect, $58 \%$ (medium category) on cognitive aspect and 56\% (moderate category) on emotional aspect. In class VIII B data students anxiety level acquired 55\% (medium category) on physical aspect, $56 \%$ (medium category) on cognitive aspect and $61 \%$ (high category) on emotional aspect. Based on these results it can be concluded that the students anxiety level in learning at Madrasah Tsanawiyah Negeri 3 Kabupaten Tebo is in medium category.
\end{abstract}

Keywords: Student Anxiety, Science Integrated Learning

\section{Introduction}

At Junior High School level/MTs, Biology, Chemistry and Physics are studied integratedly on Natural Science subjects. Depdiknas (2011) in Putri (2013)showed that integrated science learning is an approach to science teaching that connects or integrates various fields of IPA study into a single unit. Integrated science learning should also include the dimensions of attitudes, processes, products, applications, and creativity in the learning environment and students are expected to have holistic science knowledge to deal with daily life issues contextually through integrated science learning. The breadth of the scope of the Integrated IPA learning that must be mastered by the students requires readiness in the implementation of the learning processbecause students' readiness in receiving the lessons will ultimately affects the learning outcomes. Soejanto (1991) in Dessy Mulyani (2013, p. 27 28)showed that students' readiness is very important to achieve success in learning activities. The success of students doing readiness before following the lesson can determine the success of students in learning, so that it will affect student's achievement. If the student is not ready to accept the lesson, it will affect the student's psychic condition. For example, the student feels nerveous when the teacher askshim/herto stand in front of the class.

According to MOH RI (1990) in Ika (2014, p. 126) anxiety is a tension, insecurity and anxiety arising from perceived unpleasantness.anxiety can also be interpreted as someone's excessive concern for the future and his past as well as his abilities (Cowden, 2010). In each 
student, the symptoms of anxiety that appear are different.Usually it is seen from the physical conditions that ultimately affect the ability of these students in learning. Robert Priest in Namora (2009, p. 15-16) reveals that in times of anxiety the body reacts to physical reactions including the throbbing symptoms; trembling; tension; anxious and restless. Related to learning, there are two kinds of anxiety, survival anxiety and learning anxiety. Learning anxiety can arise because of fear of trying new things that are feared to be too difficult to do, besides that fear will make us look stupid in the effort. Learning anxiety is also influenced by concerns to get out of the comfort zone that has been lived. However, learning anxiety will always be there but if students accept and understand their need to learn, then this can be overcome (Coutu, 2012). Bolliger \& Halupa (2012) found that there was a real relationship between anxiety and satisfaction in learning. It can be stated that students who have low or moderate levels of anxiety have a high level of satisfaction and the other hand.

The results of observationwhich is conductedat MTs N 3 of Tebo District on February 13th, 2017 showed thatthere are some symptoms such as sound and shaking legs, cold sweats, disturbed concentration, and nervousness. All of these symptoms occur when the student is asked by the teacher or asked to speak in front of the class, this is done by the teacher to keep the students focus during the learning but not all students match with the method of learning like this. Based on the results of the study, shows that anxiety affects academic achievement (Harris \& Coy, 2003; McCraty, 2003 in Yaman (2014, p. 1118), mathematical connection ability (Ika, 2014), attitudes and retention (Elliot \& Smith, 2003; Gaudry \& Spielberger, 1971; Levitt, 1966; Miller et al, 2001 in Hullinger \& Hogan, 2014, page 32). In addition anxiety can be affected by increase of grade level, mother and father education level and decrease on academic achievement scores for science lesson (Karakaya et al, 2016, page 29). If this anxiety is not delt immediately, it can lead to other disorders such as panic and stress, but if it can be controlled, the students will gain optimal learning achievement. Based on the problems above, it is necessary to analyze the Anxiety level in integrated science learning process.

\section{Research Method}

This research is a qualitative descriptive research. The subject of the study were the students of class VIII MTs Negeri 3 Tebo Regency. The total number of the subject was40 whih were divided into 2 classes namely class VIII A and class VIII B.

The data were obtained through anxiety questionnaire which consisted of 20 statements which were analyzed by using Likert Scale, 5 answer choices consisting of Very Frequently (SS), Frequently (S), Rarely (J), Ocassionaly (KK), Never (TP). The average score of student anxiety level was then categorized by percentage as seen in table 1 below:

Table 1. Category of Anxiety Questionnaire Score

\begin{tabular}{cc}
\hline Percentage $(\boldsymbol{\%})$ & Category \\
\hline $81-100$ & Very high \\
$61-80$ & High \\
$41-60$ & Average \\
$21-40$ & Low \\
$0-20$ & Very low \\
\hline
\end{tabular}


In addition, the data were also obtained from the interview and observation on the implementation of learning in the classroom. Symptoms of student's anxiety that were studied includedthe physical, cognitive and emotional aspects.

\section{Results And Discussion}

After tested the validity and reliability of the questionnaire, it was obtained the result that there were 20 statements declared valid and reliable to use.The results of the questionnaire showed that there were three aspects which have anxiety ranges between $50-60 \%$ with the details in table 2 below:

Table 2. Total Average Score of Anxiety Questionnaire

\begin{tabular}{|c|c|c|}
\hline Aspects & VIII A & VIII B \\
\hline Physical & $50 \%$ & $55 \%$ \\
\hline Cognitive & $58 \%$ & $56 \%$ \\
\hline Emotional & $56 \%$ & $61 \%$ \\
\hline
\end{tabular}

Table 2 above shows fluctuations in the percentage of anxiety levels on the physical, cognitive and emotional aspects. The students' anxiety level was categorized Medium category.The emotional anxiety aspect in class VIII B is at High category. Basically the relationship of anxiety level of students in the learning process is very importantbecause if students are too anxious in the process of learning, the learning process cannot runs efficiently.

Some of the students which were interviewed said they felt anxious when they are asked to come to the front of the class. The anxiety makes the body tremble and the heart beat fast resulting in shame, nervousness, fear and tension. This is in line with the teachers' statement. Furthermore, the teachers stated that the things that cause the anxiety that wereexperienced by the students are they are not ready to receive the lesson, many students who play games when the teacher convey the material and they do not listen to the material explanation conveyed by the teacher. The teacher also stated that the student's attitude can be solved by themselves because the anxiety they feel comes from themselves.

What the students expressed was supported by the observations in the learning process. It seemed that the students were lack of attention in the learning process. It is indicated by some students who were chatting and playing games in the classroom, bored; saturated and drowsy. It is assumed that the problem caused by the lack of method and media used by the teacher, therefore, the students were lack of attention and not interested in the lesson.Basically, the teachers play an important role in creating an active and fun learning atmosphere. Fisher (1988) in Novita and Anita (2006)states that classroom teachers can help to reduce students' anxiety by creating an interesting classroom atmosphere, such as using humor, games and activities with a high level of relaxation. Students' anxiety can also be reduced by providing students with a sense of security, a relaxed but organized atmosphere, as well as a wellorganized curriculum and schedule. Competitive class situations should also not be implemented. Basically, teachers are expected to apply a method of learning that can reduce 
students' anxiety levels. As a result, the students' behavior and achievement can be better. When the environment in which the student is in support (both at home and at school) they can get success and good academic experience (Cowden, 2010).

Grainger in Sri (2010, p. 13-14) suggests that individuals make decisions about their anxiety based on two factors namely internal factors and external factors. The internal factors are related to everything that comes fromthe inside of the student that supports learning, such as intelligence, talent, motor skills of the senses, and thinking scheme. External factors are everything that comes from outside of the studentsthat condition them in learning. For example, experience, social environment, teaching-learning methods, learning strategies, learning facilities.

Basically, every individual is always trying to overcome anxiety by making adjustments to the causes of anxiety arise. This anxious reaction describes the subjective feelings that arise in the form of uncomfortable tension. Based on that, Burhnham in Sri (2010: p.13-14) who said that the source of anxiety would be more easily explored by examining three basic causes: 1) confidence that may be threatened by doubt about outward appearance and ability 2) our personal well-being may be threatened by uncertainty about the future, doubts in decision making and material concerns, 3) our well-being may be threatened by unsolved conflicts.

People with anxiety disorders generally often struggle with anxiety that is difficult to control.Their attempts to control fear usually fail and they suffer from a number of symptoms, both physical and psychological affecting social aspects, occupations and life functions in general.They are very easy helpless and often feel depressed and difficult to focus, sometimes they feel so great tension so that they can not to think. When this disorder arises in children, the anxiety and fear they feel is usually associated with school performance or athletic activity. They constantly feel worried, if they cannot do schoolwork, even they are worried about the situation when they are not evaluated. Most cases occur when the individual is at a young age.

Basically anxiety in low and moderate levels have a positive effect on student learning performance, one of which can increase learning motivation (Supri et al, 2013, p. 287), but it will contribute to learner if his/her target is significant. Because of this, families, school administrators and teachers should not be in ideas and expectations that will increase learning anxiety on learner (Karakaya et al, 2016, page 29). Some things that can be done by teacher to reduce the level of student learning anxiety is problem-based learning, discussing with students the test procedures that can be done by them, sharing knowledge and testing skills. Parents can teach their children the skills that needed to have control over the lesson. With this assistance both teachers and parents play a role in controlling the learning anxiety felt by students (Dobson, 2012: p. 32).

\section{Conclusion}

From the results and data analysis, it can be concluded that the level of anxiety students in the learning process in MTs Negeri 3 Kabupaten Tebo are categorized as moderate level. The factorsof anxiety are the unpreparedness of students in receiving lessons and the lack of attention and interest of students in the learning process. 


\section{References}

[1] Bolluger, DU \& Halupa, C.: Student Perception of Satisfaction and Anxiety in an Online Doctoral Program. Distance Education. 33(1), 81-98. https://doi.org/10.1080/01587919.2012.667961 . (2012)

[2] Dessy Mulyani.: Hubungan Kesiapan Belajar Siswa Dengan Prestasi Belajar, KONSELOR Jurnal Ilmiah Konseling, Vol.2, No.1, Juni 2006 (2013)

[3] Dobson, Cassie.: Effect of Academic Anxiety on The Performance of Students With And Without Learning Disabilities and How Students Can Cope With Anxiety at School. Retrieved from: https://www.nmu.edu/education/sites/DrupalEducation/files/UserFiles/Dobson_Cassie_MP.pdf (2012)

[4] Coutu, Diane.: The Anxiety of Learning. Harvard Business Review. https://hbr.org/2002/03/theanxiety-of-learning. (2002)

[5] Cowden, Peter.: Communication and Coflict: Anxiety and Learning. Research in Higher Education Journal. Retrieved from: http://www.aabri.com/manuscripts/10517.pdf (2010)

[6] Hullinger, Megan \& Hogan, RL.: Study Anxiety: Effect of A New Graduate Student Orientation Program, Administrative Issues Journal: Connecting Education, Practice And Research, 4(2), 27-34 (2014)

[7] Ika Wahyu Anita.: Pengaruh Kecemasan Matematika (Mathematic Anxiety) Terhadap Kemampuan Koneksi Matematis Siswa SMP, INFINITY, Jurnal Ilmiah Program Studi Matematika STKIP Siliwangi Bandung, Vol.3, No.1, Februari 2014, 125-132. (2014)

[8] Karakaya. Ferhat, Avgin. S. S, Kumperli. E.: Analysis of Primary School Student's Science Learning Anxiety According to Some Variables, Journal of Education and Practice, 7(33), 24-31. (2016)

[9] Namora Lubis Lumongga.: Depresi Tinjauan Psikologi. Jakarta : Kencana (2009)

[10] Novita Eka Indiyani dan Anita Listiara.: Efektifitas Model Pembelajaran Gotong Royong (Cooperative Learning) Untuk Menurunkan Kecemasan Siswa Dalam Menghadapi Pelajaran Matematika (Studi Eksperimental pada Siswa di SMP 26 Semarang). Jurnal Psikologi Universitas Diponegoro, Vol.3, No. 1, Juni 2006. (2006)

[11] Putri Anjarsari.: Pengembangan Pembelajaran IPA Terpadu (Implementasi Kurikulum 2013). Makalah disampaikan dalam PPM Workshop Pengembangan Perangkat Pembelajaran Sains Terpadu untuk Meningkatkan Kognitif, Keterampilan Proses, Kreativitas, serta Menerapkan Konsep Ilmiah Siswa SMP,7-12 September 2013, Yogyakarta (2013)

[12] Sri Supriyantini.: Perbedaan Kecemasan Dalam Menghadapi Ujian Antara Siswa Program Reguler dengan Siswa Program Akselerasi. Medan : Fakultas Psikologi Universitas Sumatra Utara (2010)

[13] Somov, A.: Wildfire safety with wireless sensor networks. EAI Endorsed Transactions on Ambient Systems. pp. 1-11 (2011)

[14] Supri. Y, Erlamsyah, Zikra, Zadrian. A.: Hubungan Antara Kecemasan Dalam Belajar Dengan Motivasi Belajar Siswa, Konselor: Jurnal Ilmiah Konseling, 2(1), 283-288. (2013)

[15] Yaman, Havva.: The Relation General Anxiety Levels, Anxiety of Writing and Attitude for Turkish Course of Secondary School Students, Educational Science: Theory \& Practice, 14(3),1117$1122(2014)$ 